\title{
Specific Surface Area Characteristic Analysis of Porous Carbon Prepared from Lignin-Polyacrylonitrile Copolymer by Activation Conditions ${ }^{1}{ }_{(\mathbb{P} P \mathbb{P}}$
}

\author{
Hyunsu $\mathrm{LEE}^{2} \cdot$ Seokju KIM(D) ${ }^{2, \uparrow} \cdot \mathrm{Mi}-\mathrm{Jin} \mathrm{PARK}^{2}$
}

\begin{abstract}
In this study, we investigated the effect of temperature on specific surface area and electrochemical properties when lignin-based porous carbon (LBPC) with potassium hydroxide (KOH) is activated. After preparing LBPCs using lignin-polyacrylonitrile (PAN) copolymer, which was synthesized by graft polymerizing lignin and acrylonitrile as a precursor, activated LBPCs (KA-LBPC-6, 7, 8, 9) were manufactured by activating $\mathrm{LBPC}$ with $\mathrm{KOH}$ at $600^{\circ} \mathrm{C}, 700^{\circ} \mathrm{C}$, $800^{\circ} \mathrm{C}$ and $900^{\circ} \mathrm{C}$. To identify the surface characteristics of KA-LBPC, observations were made with a scanning electron microscopy (SEM), and the pore characteristics were identified via specific surface area analysis. The electrochemical properties were analyzed using a three-electrode system. The experiment has shown that micropores formed by activation can be observed in SEM images. KA-LBPC-7 had the best pore characteristics among KA-LBPCs, with a specific surface area of $2480.1 \mathrm{~m}^{2} / \mathrm{g}$, a micropore volume of $0.64 \mathrm{~cm}^{3} / \mathrm{g}$, and a mesopore volume of $0.76 \mathrm{~cm}^{3} / \mathrm{g}$. KA-LBPC-7 showed the best electrochemical properties with a specific capacitance of $151.3 \mathrm{~F} / \mathrm{g}$ at the scan rate of $2 \mathrm{mV} / \mathrm{s}$.
\end{abstract}

Keywords: kraft lignin, lignin-PAN copolymer, porous carbon, $\mathrm{KOH}$ activation, specific surface area

\section{INTRODUCTION}

Environmental pollution and carbon dioxide emissions resulting from fossil fuel use are the important factors that hinder sustainable development, and with the emphasis on the importance of sustainable development, there are active movements to develop eco-friendly, high-efficiency energy storage systems (Hatfield-Dodds et al., 2017; Zhang et al., 2017). Supercapacitor is an energy storage system characterized by high power density, short charging time, and excellent durability (Zhai et al., 2011; Wang et al., 2018). To improve the capacitance of the supercapacitor, increasing the electrode material's electrical conductivity and enlarging the specific surface area for enhancing the capacity to store ions is important. Especially when the pore diameter is less than $2 \mathrm{~nm}$, the electrolyte ions cannot be adsorbed into the pores. Therefore, ensuring that many pores sizes between 2 and $5 \mathrm{~nm}$ are produced is important (Conway, 1999; Park and Kim, 2005). Carbon materials such as porous carbon, carbon nanotubes, graphene, graphite, carbon fiber, having low toxicity, high porosity and high specific surface area, and high physical and chemical stability and good electrical conductivity, are often used as electrodes for supercapacitors (Dutta et al., 2014; Wang et al., 2016). Most of the current commercially produced carbon materials nowadays are coal tar,

\footnotetext{
${ }^{1}$ Date Received April 21, 2021, Date Accepted May 29, 2021

${ }^{2}$ Forest Industrial Materials Division, National Institute of Forest Science, Seoul, 02455, Republic of Korea

$\dagger$ Corresponding author: Seokju KIM (e-mail: momoston@korea.kr, ORCID: 0000-0002-6869-8412)
} 
pitch, and polyacrylonitrile (PAN) that are derived from fossil fuels. PANs in particular are expensive, and therefore many studies are being conducted to replace them with renewable biomass (Sudo and Shimizu, 1992; Kubo et al., 1998; Kadla et al., 2002; Kubo and Kadla, 2005; Ibrahim et al., 2010; Qin and Kadla, 2011; Baker et al., 2012; Chen et al., 2021; Kang et al., 2021).

Lignin, which constitutes lignocellulosic biomass along with cellulose and hemicellulose, is the second most abundant biopolymer on Earth (Renders et al., 2017). Although it is generated in large quantities as a byproduct of biofuel production and pulping processes, it is structurally a highly complex nonconstant macromolecule and is mostly used as a low-grade source of heat due to its low reactivity in spite of having various functional groups such as hydroxyl group, carbonyl group, and methoxyl group (Nicholson and Hammerschmidt, 1992; Lora and Glasser, 2002; Calvo-Flores and Dobado, 2010). Despite these shortcomings, it is structurally rich in aromatic rings, which have the advantage of high carbon content and biodegradability, making it highly likely to be a raw material for various chemicals or materials (Suhas et al., 2007; Kai et al., 2016; Han et al., 2017; Hong et al., 2017; Kim et al., 2017; Min and Um, 2017; Hwang and Choi, 2018; Fatriasari et al., 2020).

In a previous study, lignin-PAN copolymer was prepared by graft polymerizing kraft lignin (KL) with acrylonitrile in order to use lignin as a precursor of carbon nanofiber mats (Youe et al., 2016), and the physical and chemical properties of the copolymer were observed. According to this study, the thermal stability of lignin-PAN copolymer was superior than that of individual lignin or PAN, and carbon nanofibre mats manufactured from lignin-PAN copolymer showed higher electrical conductivity than carbon nanofibre mats manufactured from PAN alone. This implies the potential of lignin-PAN copolymer being used as electrode material for energy storage devices (Panapoy et al., 2008; You et al., 2016).

In this study, activation conditions showing high specific surface area were investigated to manufacture lignin-based porous carbon (LBPC) that can be used as electrode materials for energy storage devices using lignin-PAN copolymer. The LBPC was manufactured by carbonizing lignin-PAN copolymer at high temperatures. Activation conditions for LBPC to have a high specific surface area were investigated by performing scanning electron microscope/energy-dispersive X-ray spectroscopy (SEM-EDS) and specific surface area analysis on LBPC activated with $\mathrm{KOH}$ (KA-LBPC) with different temperatures. The relationship between specific surface area and capacitance was investigated through electrochemical characterization using a three-electrode system.

\section{MATERIALS and METHODS}

\subsection{Materials}

The black liquor used in this study was provided by the Moorim P\&P, Korea. In preparing the LBPC, hydrochloric acid $(\mathrm{HCl}$, guaranteed reagent, Daejung Chemicals \& Metals, Korea), methanol (guaranteed reagent, Daejung Chemicals \& Metals, Korea), Dimethyl sulfoxide (DMSO, analytical grade, Sigma-Aldrich, USA), acrylonitrile (analytical grade, Sigma-Aldrich, USA), azobisisobutyronitrile (AIBN, guaranteed reagent, Junsei, Japan), calcium chloride $\left(\mathrm{CaCl}_{2}\right.$, guaranteed reagent, Junsei, Japan), and hydrogen peroxide $\left(\mathrm{H}_{2} \mathrm{O}_{2}\right.$, guaranteed reagent, Junsei, Japan) were used. For chemical activation, potassium hydroxide $(\mathrm{KOH}$, technical grade, Sigma-Aldrich, USA) was used. In molecular weight analysis, N,N-dimethylmethanamide (DMF, HPLC grade, Duksan Pure chemical, Korea) and lithium chloride $(\mathrm{LiCl}$, ACS reagent, Sigma-Aldrich, USA) were used. Polyvinylidene fluoride (PVDF, SigmaAldrich, USA), 1-methyl-2-pyrrolidinone (NMP, anhy- 
drous, Sigma-Aldrich, USA), carbon black (C-NERGY Super P carbon black, IMERYS Graphite \& Carbon, Switzerland), and sodium sulfate $\left(\mathrm{Na}_{2} \mathrm{SO}_{4}\right.$, guaranteed reagent, Kanto chemical, Japan) were used for analyzing electrochemical properties.

\subsection{Method of Experiment}

\subsubsection{Preparation of Methanol Soluble Kraft Lignin (KL)}

To separate $\mathrm{KL}$ from the black liquor, the $\mathrm{pH}$ of the black liquor was lowered to $\mathrm{pH} 2$ using $35 \% \mathrm{HCl}$ to precipitate lignin. KL was separated by vacuum filtering this mixture, which was washed with sufficient unionized water, and then freeze-dried afterwards. To prepare methanol soluble kraft lignin (MeKL), KL was dissolved in methanol and then vacuum filtered to separate only the filtrate. After removing methanol from the filtrate using a rotary evaporator, it was dried for over $24 \mathrm{~h}$ in an oven at $60^{\circ} \mathrm{C}$ to obtain MeKL.

\subsubsection{Preparation of Lignin-PAN Copolymer}

Lignin-PAN copolymer was prepared using the method in previous study and the chemical reaction process is shown in Fig. 1 (Youe et al., 2016). In a 250-mL round flask, DMSO (50 mL), AIBN (10 mg),

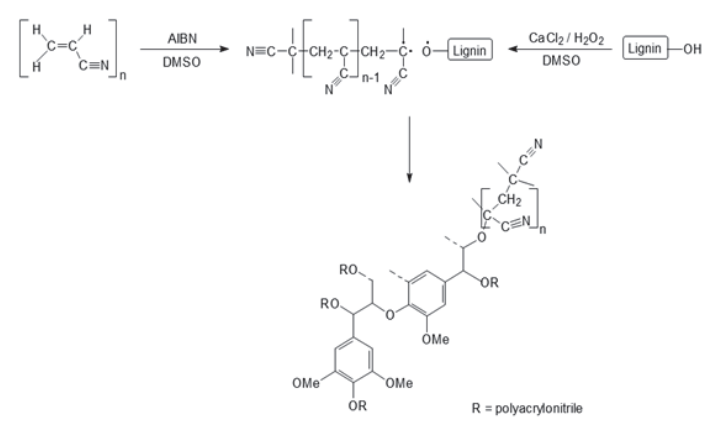

AIBN: azobisisobutyronitrile

DMSO: Dimethyl sulfoxide

Fig. 1. Chemical reaction for preparation of lignin-PAN copolymer. and acrylonitrile $(11.836 \mathrm{~mL})$ were put in. The inside of the flask was filled with nitrogen gas, then stirred at $70^{\circ} \mathrm{C}$ for $2 \mathrm{~h}$, then DMSO $(20 \mathrm{~mL})$, MeKL $(4 \mathrm{~g})$, and $\mathrm{CaCl}_{2}(8 \mathrm{~g})$ was added, stirred at $70^{\circ} \mathrm{C}$ to $900 \mathrm{rpm}$ until it completely melted, then cooled to room temperature. $30 \% \mathrm{H}_{2} \mathrm{O}_{2}(4.4 \mathrm{ml})$ was put in a flask, the inside of the flask was filled with nitrogen gas, and then stirred it at $300 \mathrm{rpm}$ at $70^{\circ} \mathrm{C}$ for $24 \mathrm{~h}$ for reaction. The reactant was placed in unionized water $(2 \mathrm{~L})$ to precipitate the lignin-PAN copolymer, filtered using filter paper (No.5A, Advantec, Japan) and a Büchner funnel, then washed and dried at $60^{\circ} \mathrm{C}$ for $24 \mathrm{~h}$. To remove unreacted MeKL and acrylonitrile, the dried lignin-PAN copolymer was mixed in methanol, filtered using the Büchner funnel, and then washed with a large amount of methanol. Then it was dried at $60^{\circ} \mathrm{C}$ for 48 $\mathrm{h}$ to obtain high-purity lignin-PAN copolymer.

\subsubsection{Property Analysis of Lignin-PAN Copolymer}

The molecular weight analysis was conducted using the Dawn Heleos-II MALLS (multiangle laser light scattering, Wyatt Technology, USA) and measured by GPCmax VE2001 (Viscotek, UK) with an Optilab T-rex RI (refractive index, Wyatt Technology, USA) detector installed. As for the column, one Agilent PLgel mixed-C $(300 \mathrm{~mm} \times 7.5 \mathrm{~mm}, 5 \mu \mathrm{m})$ and two Agilent PLgel mixed-D $(300 \mathrm{~mm} \times 7.5 \mathrm{~mm}, 5 \mu \mathrm{m})$ were connected and used while maintaining at $65^{\circ} \mathrm{C}$. A solution of $1 \mathrm{mg}$ of lignin-PAN copolymer and MeKL dissolved in 0.2-M LiCl-DMF solution ( $1 \mathrm{~mL}$ ), respectively, was analyzed using a $0.45-\mu \mathrm{m}$ syringe filter, while applying the value of $d_{n} / d_{c}$ of $0.1590 . d_{n} / d_{c}$ is a constant that represents the change in refraction index with the concentration of a solution. In Fourier-transform infrared spectroscopy (FT-IR) analysis, NICOLET iS10 (Thermo Fisher Scientific, USA) was used. The samples were scanned 128 times per sample with a resolution of $0.5 \mathrm{~cm}^{-1}$ in the measure- 
ment range of $4000-650 \mathrm{~cm}^{-1}$.

\subsubsection{Preparation of LBPC}

For thermal stabilization, the lignin-PAN copolymer was heated in a GC oven $(6890 \mathrm{~N}$, Agilent Technologies, USA) at $250^{\circ} \mathrm{C}$ for $2 \mathrm{~h}$ at a heating rate of $10^{\circ} \mathrm{C} \mathrm{min}^{-1}$. The thermally stabilized copolymer was carbonized in a high-temperature tube furnace (Nabertherm RHTH, Cole-Parmer, Germany) at $1200^{\circ} \mathrm{C}$ for $1 \mathrm{~h}$ at a heating rate of $10^{\circ} \mathrm{C} \min ^{-1}$ to obtain LBPC (Youe et al., 2016; Kim et al., 2017).

Chemical activation of LBPC was performed using $\mathrm{KOH}$. LBPC and $\mathrm{KOH}$ were mixed at a ratio of 1:4 $(\mathrm{w} / \mathrm{w})$, and placed in an alumina boat. The mixture was heat treated in a high-temperature tube furnace where nitrogen gas flows for one hour at temperatures of $600{ }^{\circ} \mathrm{C}, 700^{\circ} \mathrm{C}, 800^{\circ} \mathrm{C}$, and $900^{\circ} \mathrm{C}$ at a heating rate of $10^{\circ} \mathrm{C} \mathrm{min}{ }^{-1}$. After the activation is complete, the samples were washed with large quantities of unionized water using the Büchner funnel, and then freeze-dried to obtain KA-LBPC (KA-LBPC-6, 7, 8, 9), which were activated at $600^{\circ} \mathrm{C}, 700^{\circ} \mathrm{C}, 800^{\circ} \mathrm{C}$ and $900^{\circ} \mathrm{C}$ (Lili et al., 2004).

\subsubsection{Characterization of Porous Carbon}

The chemical and morphological properties of porous carbon were observed using SEM-EDS (JSM-7610F, JEOL, and Japan). Brunauer · Emmett · Teller (BET) specific surface area analysis was conducted at temperature $-196^{\circ} \mathrm{C}$ using BELSORP-max (MicrotracBel, Japan).

\subsubsection{Analysis of Electrochemical Properties of KA-LBPC}

KA-LBPC-6-9 (0.3 g), PVDF-based binder (PVDF: $\mathrm{NMP}=93: 7, \mathrm{w} / \mathrm{w}, 0.56 \mathrm{~g})$, and carbon black $(0.0375$ g) were mixed, and approximately $0.02-0.03 \mathrm{~g}$ of NMP was added for regulating the viscosity, then stirred at $25^{\circ} \mathrm{C}$ for $1 \mathrm{~h}$. A 0.5 -cm-wide, 4-cm-long, and 0.1-mm-thick aluminum plate was covered with 0.21 -mm-thick coating of the mixture using a micrometer film adjustable applicator (Wellcos, Korea), and was dried for $24 \mathrm{~h}$ at $65^{\circ} \mathrm{C}$ to prepare an electrode. A three-electrode system (Voltometry cell, SVC-3, Bio-Logic, USA) was constructed applying the prepared electrode as the working electrode, an $\mathrm{Ag} / \mathrm{AgCl}$ electrode as the reference electrode, and a platinum electrode as the counter electrode. $1 \mathrm{M} \mathrm{Na}_{2} \mathrm{SO}_{4}$ aqueous solution was used as the electrolyte. When measuring for all electrochemical characteristics analyses, the VSP potentiostat/galvanostat system (BioLogics, France) was used. When measuring the cyclic voltage/current (cyclic voltammetry: $\mathrm{CV}$ ), the potential range was fixed at $0-0.8 \mathrm{~V}$ in the scan rate range of $2,5,10,25,50,100$, and $200 \mathrm{mV} / \mathrm{s}$. The galvanostatic charge/discharge (GCD) test was conducted at a discharge current of 0.6-2 $\mathrm{mA}$ and a potential range of 0-0.8 V (Youe et al, 2018; Phiri et al 2019).

\section{RESULTS and DISCUSSION}

\subsection{Chemical Properties of Lignin-PAN Copolymer}

In this study, lignin-PAN copolymer was prepared using the same procedure performed by Youe et al. (2016), and conducted molecular weight analysis and

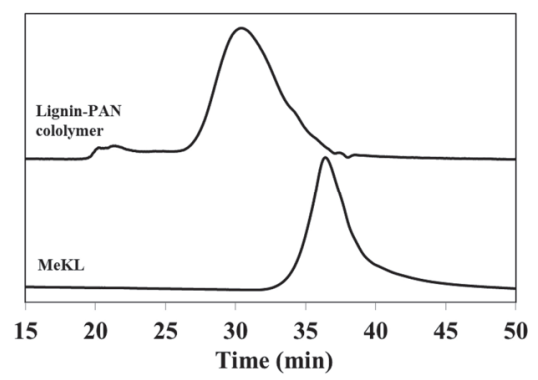

MeKL: methanol soluble kraft lignin

Fig. 2. GPC chromatogram of MeKL and lignin-PAN copolymer. 
FT-IR analysis of the prepared lignin-PAN copolymer (Youe et al., 2016). The results of molecular weight analysis of lignin-PAN copolymer and MeKL are shown in Fig. 2. The number average molecular weight

Table 1. Number average molecular weight and polydispersity index of MeKL and lignin-PAN copolymer

\begin{tabular}{ccc}
\hline & $\mathrm{M}_{\mathrm{n}}^{\mathrm{b}}(\mathrm{g} / \mathrm{mol})$ & $\mathrm{PDI}^{\mathrm{c}}\left(\mathrm{M}_{\mathrm{w}} / \mathrm{M}_{\mathrm{n}}\right)$ \\
\hline \hline $\begin{array}{c}\text { MeKL } \\
\text { Lignin-PAN } \\
\text { copolymer }\end{array}$ & $7.357 \times 10^{4}$ & 4.511 \\
\hline
\end{tabular}

a: methanol soluble kraft lignin

b: number average molecular weight

c: polydispersity index

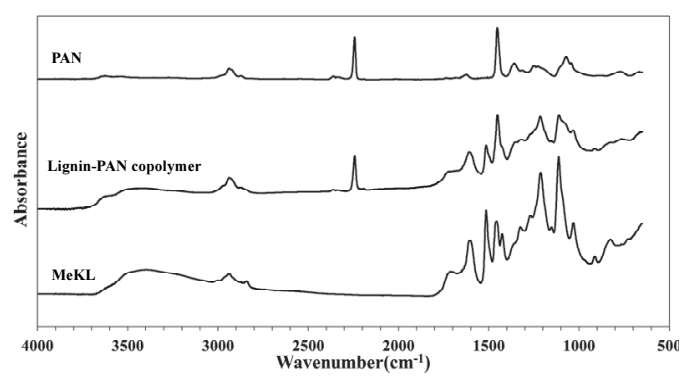

PAN: polyacrylonitrile

MeKL: methanol soluble lignin

Fig. 3. FT-IR spectra of MeKL, PAN and lignin-PAN copolymer.
$\left(\mathrm{M}_{\mathrm{n}}\right)$ and the value of polydispersity index (PDI) calculated based on Fig. 2 are shown in Table $1 . M_{n}$ of the lignin-PAN copolymer was $7.656 \times 10^{5} \mathrm{~g} / \mathrm{mol}$, which increased about 10 times that of MeKL. On the other hand, the PDI was 1.196, lower than PDI of MeKL of 4.511. This result is similar to that of the previous study: a 17.5-fold increase in $\mathrm{M}_{\mathrm{n}}$ of LigninPAN copolymer and a 7.5-fold increase in MeKL. (Youe et al., 2016). The FT-IR analysis results of lignin-PAN copolymer and MeKL and PAN are shown in Fig. 3. In the spectra of lignin-PAN copolymer, the $\mathrm{C} \equiv \mathrm{N}$ bond stretching vibration peak, which does not occur in MeKL, occurred near $2250 \mathrm{~cm}^{-1}$ and also the vibration-induced peak of aromatic ring frame, which does not occur in PAN, occurred near $1510 \mathrm{~cm}^{-1}$ (Youe et al., 2016). Combining these two results, we confirmed that the lignin-PAN copolymer has been prepared as in previous studies.

\subsection{Specific Surface Area Property of LBPC}

Fig. 4 shows SEM images of the LBPC and KALBPC-6-9. LBPC had sparsely placed large pores, otherwise the surface was generally smooth, but
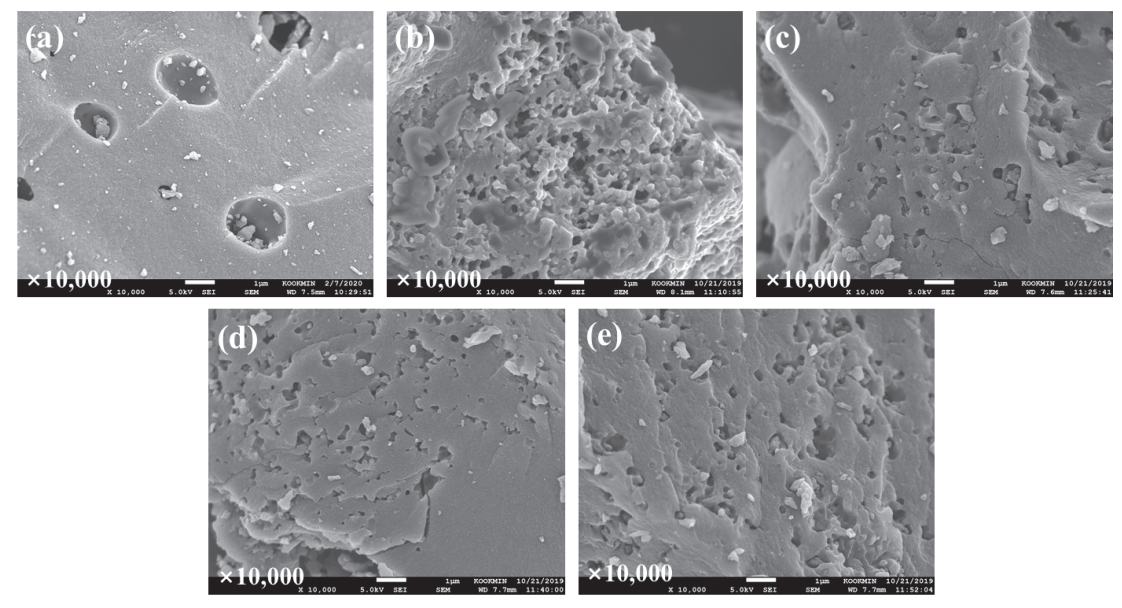

Fig. 4. SEM images of (a) LBPC, (b) KA-LBPC-6, (c) KA-LBPC-7, (d) KA-LBPC-8 and (e) KA-LBPC-9. 
KA-LBPC-6-9 showed many fine pores. This seems to have been formed owing to $\mathrm{KOH}$ activation. However, visually, the difference in pore growth with the activation temperature could not be clearly confirmed. The chemical element contents found on the surface of LBPC and KA-LBPC-6-9 using SEM-EDS are organized in Table 2. The carbon content of the LBPC was over 99\%, which confirmed good carbonization. Unlike LBPC, KA-LBPC-6-9 had slightly lower carbon content and showed oxygen, potassium, copper, zinc. It is considered that LBPC was partially doped with potassium, oxygen, and impurities in the reagent during the $\mathrm{KOH}$ activation process.

Carbon materials, if chemically and physically activated, come to have increased specific surface area owing to micro/mesopores generated within the material. These micropores and mesopores provide ion adsorption sites to increase the ion transport capacity of electrolytes (Xia et al., 2008; Jiang et al., 2020). The changes in the specific surface area with $\mathrm{KOH}$ activation temperature were shown in Table 3 using Brunauerm-Emmett-Teller (BET) analysis. LBPC had a specific low surface area of $12.8 \mathrm{~m}^{2} / \mathrm{g}$, and KA-LBPC-6, KA-LBPC-7, KA-LBPC-8 had a specific

Table 2. Surface element contents from SEM-EDS analysis of LBPC, KA-LBPC-6, 7, 8 and 9

\begin{tabular}{cccccc}
\hline \multirow{2}{*}{ Element } & \multicolumn{5}{c}{ Atom $(\%)$} \\
\cline { 2 - 6 } & LBPC & KA-LBPC-6 & KA-LBPC-7 & KA-LBPC-8 & KA-LBPC-9 \\
\hline \hline Carbon & 99.84 & 92.32 & 95.35 & 96.49 & 95.15 \\
Oxygen & - & 5.39 & 4.29 & 2.94 & 3.95 \\
Potassium & - & 1.98 & 0.15 & 0.28 & 0.57 \\
Copper & 0.13 & 0.14 & 0.14 & 0.17 & 0.21 \\
Zinc & - & 0.17 & 0.07 & - & 0.12 \\
Calcium & 0.03 & - & - & 100.00 & - \\
\hline Total & 100.00 & 100.00 & 100.00 & 100.00 \\
\hline
\end{tabular}

LBPC: non-activated and carbonized Lignin-PAN copolymer

KA-LBPC-x: KOH activated and carbonized Lignin-PAN copolymer

Table 3. BET analysis results of lignin-based porous carbon materials by activation conditions

\begin{tabular}{ccccccccc}
\hline Activation source & Sample & \multicolumn{1}{c}{$\mathrm{S}_{\text {BET }}{ }^{\mathrm{a}}$} & $\mathrm{d}_{\text {ave }}{ }^{\mathrm{b}}$ & $\mathrm{V}_{\text {micro }}{ }^{\mathrm{c}}$ & $\mathrm{V}_{\text {meso }}{ }^{\mathrm{d}}$ & $\mathrm{V}_{\text {total }} \mathrm{e}^{\mathrm{f}}$ & $\mathrm{V}_{\text {micro }} / \mathrm{V}_{\text {total }}{ }^{\mathrm{f}}$ & $\mathrm{Yield}^{\mathrm{g}}$ \\
\hline \hline \multirow{6}{*}{-} & LBPC & 45.8 & 2.38 & 0.02 & 0.17 & 0.19 & 0.1053 & - \\
\hline \multirow{2}{*}{$\mathrm{KOH}$} & KA-LBPC-6 & 1017.9 & 1.81 & 0.37 & 0.09 & 0.46 & 0.8043 & 80 \\
& KA-LBPC-7 & 2480.1 & 2.26 & 0.64 & 0.76 & 1.40 & 0.4571 & 72 \\
& KA-LBPC-8 & 1192.2 & 1.89 & 0.44 & 0.12 & 0.56 & 0.7857 & 64 \\
& KA-LBPC-9 & 666.5 & 2.72 & 0.14 & 0.31 & 0.45 & 0.3111 & 35 \\
\hline
\end{tabular}

\footnotetext{
a: specific surface area $\left(\mathrm{m}^{2} / \mathrm{g}\right)$

b: mean pore diameter $(\mathrm{nm})$

c: micropore volume $\left(\mathrm{cm}^{3} / \mathrm{g}\right)$

$\mathrm{d}$ : mesopore volume $\left(\mathrm{cm}^{3} / \mathrm{g}\right)$

e: total pore volume $\left(\mathrm{cm}^{3} / \mathrm{g}\right)$

$\mathrm{f}$ : micropore fraction to total pore volume

g: yield of LBPC after activation (\%)

LBPC: non-activated and carbonized Lignin-PAN copolymer

KA-LBPC-x: KOH activated and carbonized Lignin-PAN copolymer
} 
surface area of $1017.9,2480.1$, and $1192.2 \mathrm{~m}^{2} / \mathrm{g}$, respectively, indicating that $\mathrm{KOH}$ activation significantly increased LBPC's specific surface area. The specific surface area was found to be the largest when the activation temperature was $700^{\circ} \mathrm{C}$, which decreased
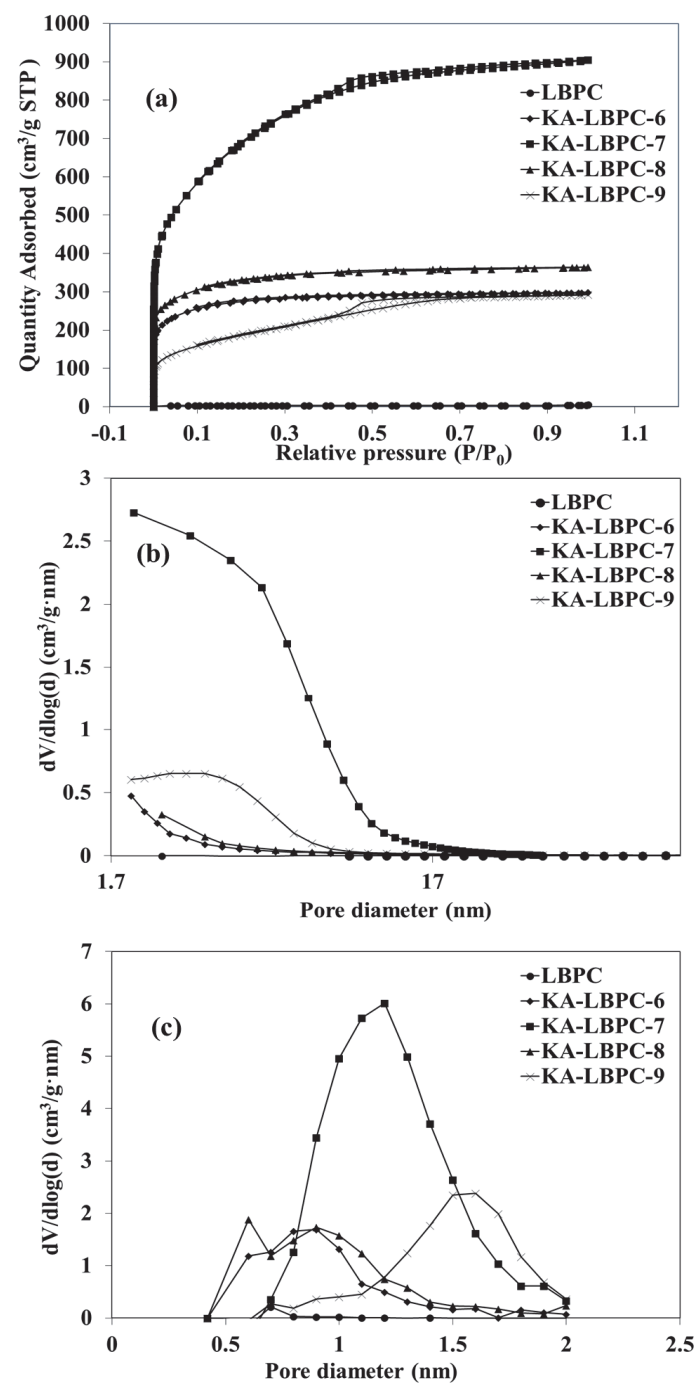

LBPC: non-activated and carbonized Lignin-PAN copolymer KA-LBPC-x: KOH activated and carbonized Lignin-PAN copolymer

Fig. 5. BET analysis results of LBPC, KA-LBPC-6, 7, 8 and 9. (a) Nitrogen adsorption and desorption isotherms (b) BJH pore size distribution (c) MP plot. at higher temperatures. It seems that the specific surface area increases with the formation of micropores and mesopores up to $700^{\circ} \mathrm{C}$, but at temperatures above $700^{\circ} \mathrm{C}$, the porous carbon overactivation causes the porous structure to collapse and the specific surface area to decrease (Kim and Hong, 1998; Rambabu et al., 2013). Several other studies have ever reported that the specific surface area decreases when carbon material is activated above a certain temperature (Kang et al., 2007; Jung et al., 2007; Lee et al., 2012).

Nitrogen adsorption/desorption isotherms of LBPC and KA-LBPC-6 to 9 are shown in Fig. 5(a). KALBPC- 6 to 9 showed the shape of type I classified using BET (Brunauer et al., 1938). Nitrogen adsorption/desorption isotherm is a measurement of the nitrogen adsorption/desorption volume of a sample at a certain fixed temperature, and we can use it calculate the specific surface area of the sample. The adsorption of LBPC was minimal, and KA-LBPC-6 and KA-LBPC-8 were mostly adsorbed up to 0.1 relative pressure $\left(\mathrm{P} / \mathrm{P}_{0}\right)$ and showed constant adsorption after 0.1. In slight contrast, KA-LBPC-7 and KA-LBPC-9 showed increasing adsorption up to $\mathrm{P} / \mathrm{P}_{0} 0.7$. This is presumably because KA-LBPC- 6 and 8 and KA-LBPC-7 and 9 are of similar micropore fraction ratio. KA-LBPC-7 had the highest final adsorption quantity, followed by KA-LBPC-8, KA-LBPC-6, and KA-LBPC-9 in order. This was the same as the result regarding the specific surface area.

Fig. 5(b) is Barrett, Joyner, and Halenda's (BJH) graphs of LBPC and KA-LBPC-6 to 9. In these graphs, mesopore distributions with a size greater than $2 \mathrm{~nm}$ can be identified. The mesopores appeared the most in the range of 2-20 $\mathrm{nm}$ in KA-LBPC-7, and other samples except KA-LBPC-7 showed a minimal formation of the mesopores.

Fig. 5(c) shows the micropore (MP) distribution of LBPC and KA-LBPC- 6 to 9 the degree of micropore formation by diameter can be identified. The size dis- 
tribution of micropores was the largest approximately $0.9 \mathrm{~nm}, 1.2 \mathrm{~nm}$, and $1.6 \mathrm{~nm}$ in KA-LBPC-6 and 8, KA-LBPC-7, and in KA-LBPC-9, respectively.

\subsection{Electrochemical Properties of LBPC}

Current-density-voltage (CV) curves at all scan rates of KA-LBPC-6-9 are shown in Fig. 6(a), 6(b), 6(c), and 6(d), respectively. The CV curves of KA-LBPC- 6-9 were all inclined spindle-shaped curves. Fig. 6(e) is a collection of the CV curves of KA-LBPC-6 to 9 at a scan rate of $200 \mathrm{mV} / \mathrm{s}$. The area of the $\mathrm{CV}$ curve with applied voltage on the $\mathrm{x}$-axis and current density on the $y$-axis is the electrical charge quantity per unit area. The area of the CV curve on Fig. 6(e) was the largest in KA-LBPC-7, and decreased in the order of KA-LBPC-8, 9, and 6. The specific capacitance calculated from the $\mathrm{CV}$ curve is shown in Fig. 6(f). In the range of scan rate of $2-200 \mathrm{mV} / \mathrm{s}$, the specific capacitance of KA-LBPC-6 was 16.7, 14.3, 12.7, 10.5, 8.9,
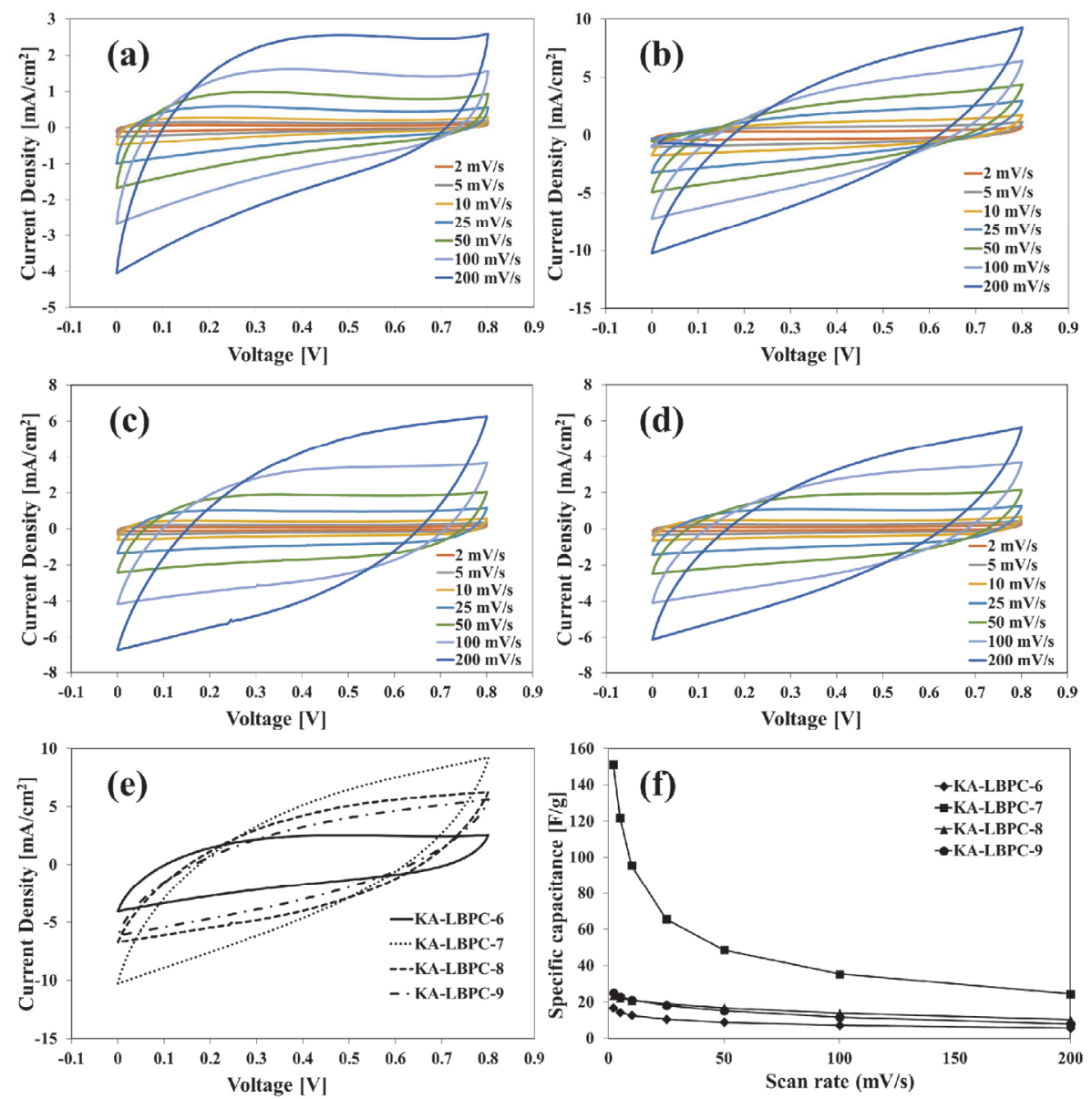

LBPC: non-activated and carbonized Lignin-PAN copolymer

KA-LBPC-x: $\mathrm{KOH}$ activated and carbonized Lignin-PAN copolymer

Fig. 6. CV curves of (a) KA-LBPC-6, (b) KA-LBPC-7, (c) KA-LBPC-8, (d) KA-LBPC-9, (e) KA-LBPC-6 9 at $200 \mathrm{mV} / \mathrm{s}$; (f) Specific capacitance of the KA-LBPC-6 9 vs scan rates. 


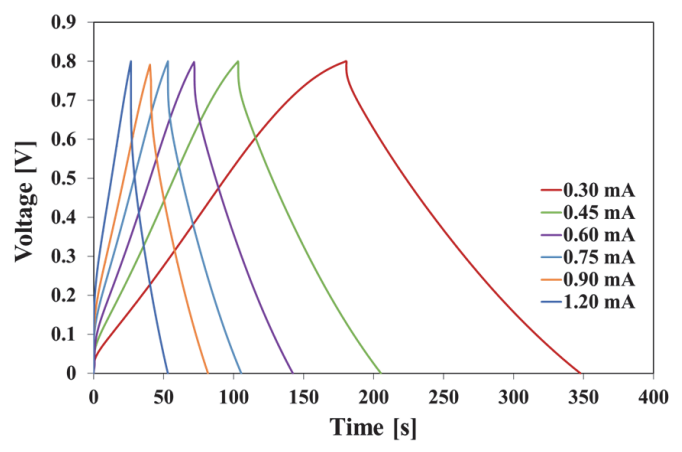

Fig. 7. GCD curves of KA-LBPC-7.

7.2, 5.6 F/g, that of KA-LBPC-7 was $151.3,121.9$, 95.6, 65.6, 48.7, 35.4, 24.6 F/g, that of KA-LBPC-8 was $23.7,22.2,21.0,18.9,16.8,14.0,10.3 \mathrm{~F} / \mathrm{g}$, and that of KA-LBPC-9 was 25.3, 23.0, 21.2, 18.2, 15.3, $11.7,8.0 \mathrm{~F} / \mathrm{g}$, respectively. As the micropores and mesopores grown during activation increases the ion storage capacity (Xia et al., 2008; Jiang et al., 2020), the specific capacitance also expected to increase as the specific surface area increased, but actual results did not show an increase in specific capacitance in KA-LBPC-6, 8 and 9 with the specific surface area less than $1200 \mathrm{~m}^{2} / \mathrm{g}$. On the other hand, KA-LBPC-7, which had a specific surface area of $2480.1 \mathrm{~m}^{2} / \mathrm{g}$, more than two times that of other KA-LBPCs, showed a significant increase in specific capacitance by approximately $6^{-9}$ times at $2 \mathrm{mV} / \mathrm{s}$. Fig. 7 shows the results of the charge and discharge tests of KA-LBPC-7 at a voltage range of 0.1 to $0.8 \mathrm{~V}$. The charge-discharge curve represents a better electrochemical performance as it is closer to a triangle (Kim and Park, 2011; Hur et al., 2012). In the case of KA-LBPC-7, a relatively close-to-triangle curve shape was shown.

\section{CONCLUSION}

In this study, LBPC was produced via carbonizing the lignin-PAN copolymer obtained using graft polymerizing KL and acrylonitrile. The physical and elec- trochemical properties of KA-LBPC obtained by activating $\mathrm{LBPC}$ with $\mathrm{KOH}$ in the $600^{\circ} \mathrm{C}-900^{\circ} \mathrm{C}$ temperature range, were investigated.

By observing KA-LBPC using SEM, micropores produced by $\mathrm{KOH}$ activation can be identified visually. The BET specific surface area analysis showed that $\mathrm{KOH}$ activation significantly increased the specific surface area of LBPC. Especially, KA-LBPC-7, a $\mathrm{KOH}$-activated specimen at $700^{\circ} \mathrm{C}$, showed the best specific surface area characteristic with a specific surface area of $2480.1 \mathrm{~m}^{2} / \mathrm{g}$, a micropore volume of $0.64 \mathrm{~cm}^{3} / \mathrm{g}$, and a mesopore volume of $0.76 \mathrm{~cm}^{3} / \mathrm{g}$. In addition, KA-LBPC-7 had the best specific capacitance of $151.3 \mathrm{~F} / \mathrm{g}(2 \mathrm{mV} / \mathrm{s})$.

Given that the increase in specific surface area following the growth of micropores and mesopores enhances the capacitance by increasing ion storage capacity, the most appropriate activation condition for lignin-PAN copolymer-based porous carbon to produce an electrode material for energy storage is concluded to be 1 -h activation at $700^{\circ} \mathrm{C}$ using $\mathrm{KOH}$.

\section{ACKNOWLEDGMENT}

This study was supported by 2020 Master's and Doctoral Researcher Fellowship of the National Institute of Forest Science in 2020.

\section{REFERENCES}

Baker, D.A., Gallego, N.C., Baker, F.S. 2012. On the characterization and spinning of an organic-purified lignin toward the manufacture of low-cost carbon fiber. Journal of Applied Polymer Science 124(1): 227-234.

Brunauer, S., Emmett, P.H., Teller, E. 1938. Adsorption of gases in multimo-lecular layers. Journal of the American Chemical Society 60(2): 309-319.

Calvo-Flores, F.G., Dobado, J.A. 2010. Lignin as 
Renewable Raw Material. ChemSusChem 3: 1227-1235.

Conway, B.E. 1999. Electrochemical Supercapacitors: Scientific Fundamentals and Technological Applications. Klumer Academic/Plenum Publishers, New York. Chen, S., Xia, Y., Zhang, B., Chen, H., Chen, G., Tang, S. 2021. Disassembly of lignocellulose into cellulose, hemicellulose, and lignin for preparation of porous carbon materials with enhanced performances. Journal of Hazardous Materials 408: 124956.

Dutta, S., Bhaumik, A., Wu, K.C.-W. 2014. Hierarchically porous carbon derived from polymers and biomass: Effect of interconnected pores on energy applications. Energy and Environmental Science 7(11): 3574-3592.

Fatriasari, W., Nurhanzah, F., Raniya, R., Laksana, R.P.B., Anita, S.H., Iswanto, A.H., Hermiati, E. 2020. Enzymatic hydrolysis performance of biomass by the addition of a lignin based biosurfactant. Journal of the Korean Wood Science and Technology 48(5): 651-665.

Han, S.-Y., Park, C.-W., Lee, S.-H. 2017. Preparation of lignocellulose nanofiber by mechanical defibrillation after pretreatment using cosolvent of ionic liquid and DMF. Journal of the Korean Wood Science and Technology 45(3): 268-277.

Hatfield-Dodds, S., Schandl, H., Newth, D., Obersteiner, M., Cai, Y., Baynes, T., West, J., Havlik, P. 2017. Assessing global resource use and greenhouse emissions to 2050, with ambitious resource efficiency and climate mitigation policies. Journal of Cleaner Production 144: 403-414.

Hong, C.-Y., Kim, S.-H., Park, S.-Y., Choi, J.-H., Cho, S.-M., Kim, M., Choi, I.-G. 2017. Catabolic pathway of lignin derived-aromatic compounds by whole cell of phanerochaete chrysosporium (ATCC 20696) with reducing agent. Journal of the Korean Wood Science and Technology 45(2): 168-181. Hur, J.-H., Seo, M.-K., Kim, H.-Y., Kim, I.-J., Park,
S.-J. 2012. Influence of $\mathrm{KOH}$ activation on electrochemical performance of coal tar pitch-based activated carbons for supercapacitor. Polymer 36(6): 756-760.

Hwang, H., Choi, J.W. 2018, Preparation of nanoporous activated carbon with sulfuric acid lignin and its application as a biosorbent. Journal of the Korean Wood Science and Technology 46(1): 17-28.

Ibrahim, M.N.M., Ahmed-Haras, M.R., Sipaut, C.S., Aboul-Enein, H.Y., Mohamed, A.A. 2010. Preparation and characterization of a newly water soluble lignin graft copolymer from oil palm lignocellulosic waste. Carbohydrate Polymers 80(4): 1102-1110.

Jiang, X., Guo, F., Jia, X., Liang, S., Peng, K., Qian, L. 2020. Synthesis of biomass-based porous graphitic carbon combining chemical treatment and hydrothermal carbonization as promising electrode materials for supercapacitors. Ionics 26: 3655-3668.

Jung, M.-K., Kim, S.-K., Jung, D.-H., Peck., D.-H, Shin, J.-H., Shul, Y.-G., Yoon, S.-H. 2007. Characteristics of the catalysts using activated carbon nanofibers with $\mathrm{KOH}$ as the support of anode catalyst for direct methanol fuel cell. Carbon Letters 8(1): 37-42.

Kadla, J.F., Kubo, S., Venditti, R.A., Gilbert, R.D., Compere, A.L., Griffith, W. 2002. Lignin-based carbon fibers for composite fiber applications. Carbon 40: 2913-2920.

Kang, D., Lee, Y., Park, K.H., Bae, J.S., Jo, S.M., Kim, S.S. 2021. Carbon fibers derived from oleic acidfunctionalized lignin via thermostabilization accelerated by UV irradiation. ACS Sustainable Chemistry \& Engineering 9(14): 5204-5216.

Kang, K.H., Kam, S.K., Lee, S.W., Lee, M.G. 2007. Adsorption characteristics of activated carbon prepared from waste ctrus peels by $\mathrm{NaOH}$ activation. Journal of the Environmental Sciences 16(11): 1279-1285.

Kai, D., Tan, M.J., Chee, P.L., Chua, Y.K., Yap, Y.L., Loh, X.J. 2016. Towards lignin-based functional 
materials in a sustainable world. Green Chemistry 18(5): 1175-1200.

Kim, D., Cheon, J., Kim, J., Hwang, D., Hong, I., Kwon, O.H., Park, W.H., Cho, D. 2017. Extration and characterization of lignin from black liquor and preparation of biomass-based activated carbon there-from. Carbon letters 22: 81-88.

Kim, J.-Y., Heo, S., Park, S.Y., Choi, I.-G., Choi, J.W. 2017. Selective production of monomeric phenols from lignin via two-step catalytic cracking process. Journal of the Korean Wood Science and Technology 45(3): 278-287.

Kim, K.S., Park, S.J. 2011. Influence of multi-walled carbon nanotubes on the electrochemical performance of graphene nanocomposites for supercapacitor electrodes. Electrochimica Acta 56(3): 1629-1635.

Kim, S.C., Hong, I.K. 1998. Manufacuring and physical properties of coal based activated carbon. Journal of Korean Society of Environmental Engineers 20(5): 745-754.

Kubo, S., Uraki, Y., Sano, Y. 1998. Preparation of carbon fibers from softwood lignin by atmospheric acetic acid pulping. Carbon 36(7-8): 1119-1124.

Kubo, S., Kadla, J.F. 2005. Lignin-based carbon fibers: Effect of synthetic polymer blending on fiber properties. Journal of Polymers and the Environment 13(2): 97-105.

Lee, J.-H., Heo, G.-Y., Park, S.-J. 2012. Influence of activation temperature on electrochemical performances of styrenee-acrylonitrile based porous carbons. Polymer(Korea) 36(6): 739-744.

Lili, G., Haiyan, L., Haibo, L., Xiuyun, S., Jianling, X., Dechen, L., Yang, L. 2004. KOH Direct activation for preparing acticated carbon fiber from polyacrylonitrile-based pre-oxidized fiber. Chemical Research in Chinese Universities 30(3): 441-446.

Lora, J., Glasser, W. 2002. Recent industrial applications of lignin: A sustainable alternative to nonrenewable materials. Journal of Polymers and the Environment 10(1): 39-48.

Min, C.-H., Um, B.H. 2017. Effect of process parameters and kraft lignin additive on the mechanical properties of miscanthus pellets. Journal of the Korean Wood Science and Technology 45(6): 703-719.

Nicholson, R.L., Hammerschmidt, R. 1992, Phenolic compounds and their role in disease resistance. Annual Review of Phytopathology 30(1): 369-389.

Panapoy, M., Dankeaw, A., Ksapabutr, B. 2008. Electrical conductivity of PAN-based carbon nanofibers prepared by electrospinning method. Thammasat International Journal of Science and Technology 13: 11-17.

Park, S.-J., Kim, B.-J. 2005. Carbon materials for electrochemical capacitors. Carbon Science 6(4): 257-268.

Phiri, J., Dou, J., Vuorinen, T., Gane, P.A.C., Maloney, T.C. 2019. Highly porous willow wood-derived activated carbon for high-performance supercapacitor electrodes. ACS Omega 4(19): 18108-18117.

Qin, W., Kadla, J.F. 2011. Effect of organoclay reinforcement on lignin-based carbon fibers. Industrial and Engineering Chemistry Research 50(22): 12548-12555.

Rambabu, N., Azargohar, R., Dalai, A.K., Adjaye, J. 2013. Evaluation and comparison of enrichment efficiency of physical/chemical activations and functionalized activated carbons derived from fluid petroleum coke for environmental applications. Fuel Processing Technology 106: 501-510.

Renders, T., Van den Bosch, S., Koelewijn, S.F., Schutyser, W., Sels, B.F. 2017. Lignin-first biomass fractionation: The advent of active stabilisation strategies. Energy \& Environmental Science 10(7): 1551-1557.

Sudo, K., Shimizu, K. 1992. A new carbon fiber from lignin. Journal of Applied Polymer Science 44(1): 127-134. 
Suhas, P.J., Carrott, M.M., Carrott, R. 2007. Lignin from natural adsorbent to activated carbon: A review. Bioresource Technology 98(12): 2301-2312.

Wang, Y.G., Song, Y.F., Xia, Y. 2016. Electrochemical capacitors: Mechanism, materials, systems, characterization and applications. Chemical Society Reviews 45(21): 5925-5950.

Wang, Z., Shen, D., Wu, C., Gu, S. 2018. State-of-the-art on the production and application of carbon nanomaterials from biomass. Green Chemistry 20(22): 5031-5057.

Xia, K., Gao, Q., Jiang, H.J. 2008. Hierachical porous carbons with controlled micropores and mesopores for supercapacitor electrode materials. Carbon 46(13): 1718-1726.

Youe, W.J., Lee, S.M., Lee, S.S., Lee, S.H., Kim, Y.S. 2016. Characterization of carbon nanofiber mats produced from electrospun lignin-g-polyacrylonitrile copolymer. International Journal of Biological Macromolecules 82: 497-504.

Youe, W.-J., Kim, S.J., Lee, S.-M., Chun, S.-J., Kang, J., Kim, Y.S. 2018. $\mathrm{MnO}_{2}$-deposited lignin-based carbon nanofiber mats for application as electrodes in symmetric pseudocapacitors. International Journal of Biological Macromolecules 112: 943-950.

Zhai, Y., Dou, D., Zhao, P.F., Fulvio, R.T., Mayes, Dai, S. 2011, Carbon materials for chemical capacitive energy storage. Advanced Materials 23(42): 4828-4850.

Zhang, Y., Liu, X., Wang, S., Li, L., Dou, S. 2017. Bionanotechnology in high-performance supercapacitors. Advanced Energy Materials 7(21): 1700592. 


\section{APPENDIX}

(Korean Version)

\section{리그닌-PAN 공중합체로 제조한 다공성 탄소 소재의 활성화 처리 조건에 따른 비표면적 특성 연구}

초록: 본 연구에서는 리그닌 기반 다공성 탄소(lignin-based porous carbon; LBPC)를 수산화칼륨(KOH)으로 활성화할 때 온도가 비표면적과 전기화학적 특성에 미치는 영향을 알아보았다. 리그닌과 acrylonitrile을 그라프트 중합으로 합성한 리그닌 -polyacrylonitrile (PAN) 공중합체를 전구체로 하여 $\mathrm{LBPC}$ 를 제조한 후 $\mathrm{LBPC}$ 를 $\mathrm{KOH}$ 로 $600,700,800,900^{\circ} \mathrm{C}$ 에서 활성화하여 활성화 처리한 LBPC (KA-LBPC-6, 7, 8, 9)를 제조하였다. KA-LBPC의 표면 특성을 알아보기 위해 주사전자현미경으로 관찰하였으며, 비표면적 분석을 통해 기공 특성을 파악하였다. 전기화학적 특성은 3전극 시스템으로 분석하였다. 실험 결과 SEM 사진상에서 활성화 처리에 의한 미세기공 형성을 관찰하였다. KA-LBPC-7의 비표면적은 $2480.1 \mathrm{~m}^{2} / \mathrm{g}$, 미세기공 부피는 $0.64 \mathrm{~cm}^{3} / \mathrm{g}$, 중기공 부피는 $0.76 \mathrm{~cm}^{3} / \mathrm{g}$ 으로 KA-LBPC 중에서 가장 좋은 기공 특성을 보였다. 전기화학적 특성 역시 $2 \mathrm{mV} / \mathrm{s}$ 의 주사속도에서 비정전용량이 $151.3 \mathrm{~F} / \mathrm{g}$ 이었던 KA-LBPC-7이 가장 좋은 것으로 나타났다.

\section{1. 서론}

화석 연료 사용에 의한 환경 오염 및 이산화탄소 배출은 지속 가능한 발전을 방해하는 중요한 요인 중 하나이며, 지속 가능한 발전에 대한 중요성이 강조됨에 따라 친환경 고효율 에너지 저장 장치를 개발하려는 움직임이 활발하다(Hatfield-Dodds et al., 2017; Zhang et al., 2017). 슈퍼캐패시터는 이러한 에너지 저장장치 중 하나로 높은 전력 밀도, 짧은 충전시간, 뛰어난 내구성 등을 갖고 있다는 특성이 있다(Zhai et al., 2011; Wang et al., 2018). 슈퍼캐패시터의 정전용량을 향상시키기 위해서는 전극재의 전기전도도를 높이고 비표면적을 크게 해서 이온저장능력을 높이는 것이 중요하며, 그중에서도 기공의 직경이 2 $\mathrm{nm}$ 이하일 때 전해질 이온들이 기공 내로 흡착되지 못하므로 $2 \sim 5 \mathrm{~nm}$ 크기의 기공이 많이 생성되도록 하는 것이 중요하다 (Conway, 1999; Park and Kim, 2005). 다공성 탄소, 탄소나노튜브, 그래핀, 흑연, 탄소섬유 등의 탄소 소재는 독성이 낮고 다공성 및 높은 비표면적을 가지며 물리·화학적으로 높은 안정성 및 좋은 전기 전도성을 지녀 슈퍼캐패시터의 전극 소재로 주로 이용된다(Dutta et al., 2014; Wang et al., 2016). 현재 상업적으로 생산되는 탄소 소재들의 원료 대부분은 화석연료에서 유래한 콜타르, 피치, polyacrylonitrile (PAN) 등이다. 특히 PAN은 가격이 비싸서 이를 재생 가능한 바이오매스로 대체하기 위한 많은 연구가 진행되고 있다(Sudo and Shimizu, 1992; Kubo et al., 1998; Kadla et al., 2002; Kubo and Kadla, 2005; Ibrahim et al., 2010; Qin and Kadla, 2011; Baker et al., 2012; Chen et al., 2021; Kang et al., 2021).

리그닌은 셀룰로오스, 헤미셀룰로오스와 함께 목질계 바이오매스를 구성하는 지구상에서 두번째로 풍부한 바이오 고분자이 다(Renders et al., 2017). 바이오 연료 생산 및 펄핑 공정에서 부산물로 다량 발생하지만, 구조적으로 매우 복잡하고 일정하지 않은 거대분자이며 하이드록실기, 카르보닐기, 메톡실기 등 다양한 기능기가 있음에도 불구하고 반응성이 낮아 대부분 저급의 열원으로 이용되고 있다(Nicholson와 Hammerschmidt, 1992; Lora and Glasser, 2002; Calvo-Flores and Dobado, 2010). 이런 단점에도 불구하고 구조적으로 방향족 고리가 풍부하여 탄소 함량이 높고, 생분해성이라는 장점이 있으므로 여러 화학제품이나 소재의 원료가 될 잠재성이 높다(Suhas et al., 2007; Kai et al., 2016; Han et al., 2017; Hong et al., 2017; Kim et al., 2017; Min and Um, 2017; Hwang and Choi, 2018; Fatriasari et al., 2020).

이전 연구에서는 리그닌의 소재화를 위하여 크라프트 리그닌(kraft lignin; KL)과 acrylonitrile을 그라프트 중합하여 리그닌 -PAN 공중합체를 제조하였고, 공중합체의 물리·화학적 특성을 살펴보았다(Youe et al., 2016). 이에 따르면 리그닌.PAN이 각각 단독으로 존재할 때보다 리그닌-PAN 공중합체의 열적 안정성이 향상되었고, 리그닌-PAN 공중합체로 제조한 탄소나노섬 유매트는 PAN만으로 제조한 탄소나노섬유매트보다 전기전도도가 더 높았다. 이는 리그닌-PAN 공중합체를 에너지 저장장치의 전극 소재로 이용할 잠재성이 있음을 의미한다(Panapoy et al., 2008; Youe et al., 2016).

본 연구에서는 리그닌-PAN 공중합체를 이용하여 에너지 저장장치의 전극 소재로 활용할 수 있는 리그닌 기반 다공성 탄소 (lignin-based porous carbon; LBPC)를 제조하기 위해서, 고비표면적을 나타내는 활성화 처리 조건을 조사하였다. 리그닌-PAN 공중합체를 고온에서 탄화하여 $\mathrm{LBPC}$ 를 제조하였고, 온도 조건을 다르게 하여 $\mathrm{KOH}$ 로 활성화 처리한 LBPC (LBPC activated 
Hyunsu LEE $\cdot$ Seokju KIM $\cdot$ Mi-Jin PARK

with $\mathrm{KOH} ; \mathrm{KA}-\mathrm{LBPC}$ )를 대상으로 주사전자현미경-에너지분산형분광분석(scanning electron microscope/energy-dispersive X-ray spectroscopy; SEM-EDS), 비표면적 분석을 실시하여 고비표면적을 나타내는 처리 조건을 조사하였으며, 3전극 시스템을 이용한 전기화학 특성 분석을 통해 고비표면적일수록 높은 정전용량을 보이는지 확인하였다.

\section{2. 재료 및 방법}

\section{1. 공시재료}

본 연구에서 사용한 흑액은 무림 P\&P에서 제공하였다. 리그닌 기반 다공성 탄소 제조에는 염산(hydrochloric acid, $\mathrm{HCl}$, guaranteed reagent, Daejung Chemicals \& Metals, Korea), 메탄올(methanol, guaranteed reagent, Daejung Chemicals \& Metals, Korea), Dimethyl sulfoxide (DMSO, analytical grade, Sigma-Aldrich, USA), Acrylonitrile (analytical grade, Sigma-Aldrich, USA), Azobisisobutyronitrile (AIBN, guaranteed reagent, Junsei, Japan), 염화칼슘(calcium chloride, $\mathrm{CaCl}$, guaranteed reagent, Junsei, Japan), 과산화수소(hydrogen peroxide, $\mathrm{H}_{2} \mathrm{O}_{2}$, guaranteed reagent, Junsei, Japan)을 사용하였으며 화학적 활성 화 처리에는 수산화칼륨(potassium hydroxide, $\mathrm{KOH}$, technical grade, Sigma-Aldrich, USA)을 사용하였다. 분자량 분석에는 N,N-dimethylmethanamide (DMF, HPLC grade, Duksan Pure chemical, Korea), lithium chloride (LiCl, ACS reagent, Sigma-Aldrich, USA)을 사용하였다. Polyvinylidene fluoride (PVDF, Sigma-Aldrich, USA), 1-methyl-2-pyrrolidinone (NMP, anhydrous, Sigma-Aldrich, USA), 카본블랙(C-NERGY Super P carbon black, IMERYS Graphite \& Carbon, Switzerland), 황산나트륨(sodium sulfate, $\mathrm{Na}_{2} \mathrm{SO}_{4}$, guaranteed reagent, Kanto chemical, Japan)을 전기화학적 특성 분석에 이용하였다.

\section{2. 실험 방법}

2.2.1. 메탄올 가용성 크라프트 리그닌 제조

흑액으로부터 $\mathrm{KL}$ 을 분리하기 위해 흑액의 $\mathrm{pH}$ 를 $35 \% \mathrm{HCl}$ 을 사용하여 $\mathrm{pH}$ 2까지 낮춰서 리그닌을 침전시켰고, 이 혼합물을 진공여과하여 KL을 분리하였고, 충분한 양의 증류수로 세척한 후 동결건조하였다. 메탄올 가용성 크라프트 리그닌(methanol soluble kraft lignin; MeKL)을 제조하기 위해서 KL을 메탄올에 용해한 다음 진공여과하여 여과액만 분리하였다. 감압증발기를 이용하여 여과액에서 메탄올을 제거한 후 $60^{\circ} \mathrm{C}$ 오븐에서 24시간 이상 건조하여 MeKL을 얻었다.

\subsection{2. 리그닌-PAN 공중합체 제조}

리그닌-PAN 공중합체 제조는 이전 연구에서의 방법대로 실시하였으며 그 화학반응 과정을 Fig. 1에 나타내었다(Youe et al., 2016). $250 \mathrm{~mL}$ 둥근플라스크에 DMSO $(50 \mathrm{~mL}), \mathrm{AIBN}(10 \mathrm{mg})$, acrylonitrile $(11.836 \mathrm{~mL})$ 을 넣고 플라스크 내부를 질소 기체로 채운 다음 $70^{\circ} \mathrm{C}$ 에서 2시간 교반하였고, $\mathrm{DMSO}(20 \mathrm{~mL}), \mathrm{MeKL}(4 \mathrm{~g}), \mathrm{CaCl}_{2}(8 \mathrm{~g})$ 을 넣고 $70^{\circ} \mathrm{C}$ 에서 $900 \mathrm{rpm}$ 으로 교반하여 완전히 녹인 후 상온으로 냉각하였다. $30 \% \mathrm{H}_{2} \mathrm{O}_{2}(4.4 \mathrm{ml})$ 를 플라스크에 넣고 내부를 질소 기체로 채운 후 $70^{\circ} \mathrm{C}$ 에서 $300 \mathrm{rpm}$ 으로 24 시간 동안 교반하여 반응시킨다. 이 반응물을 증류수 $(2 \mathrm{~L})$ 에 넣어 리그닌-PAN 공중합체를 침전시키고 여과지 (No.5A, Advantec, Japan)와 부흐너 깔때기를 이용하여 여과 및 세척한 후 $60^{\circ} \mathrm{C}$ 에서 24 시간 동안 건조하였다. 미반응한 MeKL 과 acrylonitrile을 제거하기 위해서 건조된 시료를 메탄올에 넣어 용해시키고, 부흐너 깔때기에서 여과 후 다량의 메탄올로 세척하였다. 그런 다음 $60^{\circ} \mathrm{C}$ 에서 48 시간 동안 건조하여 고순도의 리그닌-PAN 공중합체를 얻었다.

\subsection{3. 리그닌-PAN 공중합체의 특성 분석}

분자량 분석은 DAWN HELEOS-II MALLS (multi-angle laser light scattering, Wyatt Technology, USA), Optilab T-rex RI (refractive index, Wyatt Technology, USA) 검출기가 장착된 GPCmax VE2001 (Viscotek, UK)로 측정하였다. 컬럼은 한 개의 agilent PLgel mixed-C $(300 \times 7.5 \mathrm{~mm}, 5 \mu \mathrm{m})$ 와 두 개의 agilent PLgel mixed-D $(300 \times 7.5 \mathrm{~mm}, 5 \mu \mathrm{m})$ 를 연결하여 $65^{\circ} \mathrm{C}$ 를 유지하여 사용하였다. $1 \mathrm{mg}$ 의 리그닌-PAN 공중합체와 MeKL을 각각 $0.2 \mathrm{M} \mathrm{LiCl-DMF}$ 용액 $(1 \mathrm{~mL})$ 에 녹인 용액을 $0.45 \mu \mathrm{m}$ 시린지 필터로 여과하여 분석하였으며, $\mathrm{d}_{n} / \mathrm{d}_{\mathrm{c}}$ 값은 0.1590 을 사용하였다. $\mathrm{d}_{n} / \mathrm{d}_{\mathrm{c}}$ 란 용액의 농도에 따른 굴절률 변화를 나타낸 상수이다. FT-IR (Fourier-transform infrared spectroscopy)분석은 NICOLET iS10 (Thermo Fisher Scientific, USA)을 사용하였다. 측정범위 $4000-650 \mathrm{~cm}^{-1}$ 에서 $0.5 \mathrm{~cm}^{-1}$ 의 해상도로 시료 당 128 번 스캔하였다.

2.2.4. 리그닌 기반 다공성 탄소 제조

열안정화를 위해서 리그닌-PAN 공중합체를 GC 오븐(6890N, Agilent Technologies, USA)에서 $10{ }^{\circ} \mathrm{C} / \mathrm{min}$ 의 가열 속도로 
$250^{\circ} \mathrm{C}$ 에서 두 시간 가열하였다. 열안정화한 공중합체는 질소 기체가 흐르는 고온관상로(Nabertherm RHTH, Cole-Parmer, Germany)에 넣어 $10{ }^{\circ} \mathrm{C} / \mathrm{min}$ 의 가열 속도로 $1200^{\circ} \mathrm{C}$ 에서 1시간 동안 탄화해서 $\mathrm{LBPC}$ 를 얻었다(Youe et al., 2016; Kim et al., 2017).

$\mathrm{KOH}$ 를 사용하여 $\mathrm{LBPC}$ 의 화학적 활성화 처리를 하였다. $\mathrm{LBPC}$ 와 $\mathrm{KOH}$ 를 $1: 4(\mathrm{w} / \mathrm{w})$ 의 비율로 섞어서 알루미나 보트에 넣은 다음 질소 기체가 흐르는 고온관상로에서 $10{ }^{\circ} \mathrm{C} / \mathrm{min}$ 의 가열 속도로 $600,700,800,900^{\circ} \mathrm{C}$ 의 온도에서 1 시간 동안 열처리하 였다. 처리가 끝난 시료는 Buchner funnel을 이용하여 다량의 증류수로 세척한 다음 동결건조하여 $600,700,800,900^{\circ} \mathrm{C}$ 에서 활성화 처리한 KA-LBPC (KA-LBPC-6, 7, 8, 9)를 얻었다(Lili 등, 2004).

\subsection{5. 다공성 탄소의 특성 분석}

다공성 탄소의 화학적·형태학적 특성은 SEM-EDS (JSM-7610F, JEOL, Japan)로 관찰하였다. Brunauer:Emmett-Teller (BET) 비표면적 분석은 BELSORP-max (MicrotracBel, Japan)을 이용하여 온도 $-196^{\circ} \mathrm{C}$ 에서 분석하였다.

\subsection{6. $\mathrm{KA}-\mathrm{LBPC}$ 의 전기화학적 특성 분석}

KA-LBPC-6 9 (0.3 g)과 PVDF계 바인더(PVDF:NMP=93:7, w/w, $0.56 \mathrm{~g})$, 카본블랙(0.0375 g)을 혼합한 후 점도 조절을 위해 NMP를 약 0.02 0.03 g 더 넣고 1시간 동안 실온에서 교반하였다. 이 혼합물을 가로 $0.5 \mathrm{~cm}$, 세로 $4 \mathrm{~cm}$, 두께 $0.1 \mathrm{~mm}$ 인 알루미늄판 표면에 닥터블레이드(micrometer film adjustable applicator, Wellcos, Korea)를 이용하여 $0.21 \mathrm{~mm}$ 두께로 코팅하고 $65^{\circ} \mathrm{C}$ 에서 24 시간 건조하여 전극을 제조하였다. 제조한 전극을 작업전극, 은/염화은 전극을 기준전극, 백금 전극을 상대전극으로 하는 3전극 시스템(Voltametry cell, SVC-3, Bio-Logic, USA)을 구성하였으며, 전해질로는 $1 \mathrm{M} \mathrm{Na}_{2} \mathrm{SO}_{4}$ 수용액을 사용하였다. 모든 전기화학적 특성 분석은 VSP potentiostat/galvanostat system (BioLogics, France)을 이용하여 측정하였다. 순환 전압-전류 측정(cyclic voltammetry; CV)은 $2,5,10,25,50,100,200 \mathrm{mV} / \mathrm{s}$ 의 주사 속도범위에서 전위범위를 $0 \sim 0.8 \mathrm{~V}$ 로 고정하여 측정하였다. 충방전 시험(galvanostatic charge/discharge test; $\mathrm{GCD}$ )은 방전전류 $0.6 \sim 2 \mathrm{~mA}$, 전위범위 $0 \sim 0.8 \mathrm{~V}$ 에서 측정하였다 (Youe 등, 2018; Phiri 등 2019).

\section{3. 결과 및 고찰}

3.1. 리그닌-PAN 공중합체의 화학적 특성

본 연구에서는 Youe et al. (2016)에서 실시했던 절차와 동일하게 리그닌-PAN 공중합체를 제조하였으며, 제조한 리그닌-PAN 공중합체의 분자량 분석과 FT-IR 분석을 실시하였다(Youe et al., 2016). 리그닌-PAN 공중합체와 MeKL의 분자량 분석 결과를 Fig. 2에 나타내었으며, Fig. 2를 바탕으로 계산한 수평균분자량(number average molecular weight; $\mathrm{M}_{n}$ )과 PDI (polydispersity index) 값을 Table 1에 나타냈다. 리그닌-PAN 공중합체의 $\mathrm{M}_{\mathrm{n}}$ 은 $7.656 \times 10^{5} \mathrm{~g} / \mathrm{mol}^{2}$ 로 $\mathrm{MeKL}$ 의 $\mathrm{M}_{\mathrm{n}}$ 보다 약 10 배 이상 증가하였다. 반면 PDI는 1.196 으로 MeKL의 PDI인 4.511보다 감소하였다. 이는 이전 연구에서 리그닌-PAN 공중합체의 $\mathrm{M}_{\mathrm{n}}$ 이 MeKL의 $\mathrm{M}_{\mathrm{n}}$ 의 7.5배에서 17.5배 증가한 것과 유사한 결과이다(Youe et al., 2016). 리그닌-PAN 공중합체와 MeKL, PAN의 FT-IR 분석 결과를 Fig. 3에 나타내었다. 리그닌-PAN 공중합체의 스펙트럼에서는 MeKL에서 나타나지 않는 $2250 \mathrm{~cm}^{-1}$ 부근의 C $\equiv \mathrm{N}$ 결합 신축 진동 피크와 PAN에서 나타나지 않는 $1510 \mathrm{~cm}^{-1}$ 부근의 방향족 고리 골격의 진동에 의한 피크가 함께 나타났다(Youe et al., 2016). 이 두 결과를 종합하여 리그닌-PAN 공중합체가 이전 연구와 같이 제조되었음을 확인하였다.

\section{2. 리그닌 기반 다공성 탄소의 비표면적 특성}

Fig. 4는 LBPC와 KA-LBPC-6 9의 SEM 사진이다. LBPC는 큰 기공이 드문드문 보이며 그 외에 표면은 대체로 매끄러웠지 만, KA-LBPC-6 9은 미세한 기공들이 다수 관찰되었다. 이는 $\mathrm{KOH}$ 활성화 처리로 형성된 것으로 보인다. 그러나 활성화 처리 온도에 따른 기공 성장의 차이는 시각적으로 명확하게 확인할 수는 없었다. SEM-EDS를 이용한 LBPC와 KA-LBPC-6 9의 표면 원소 함량을 Table 2에 정리하였다. LBPC의 탄소 함량은 $99 \%$ 이상으로 탄화가 잘 되었음을 확인하였다. KA-LBPC-6 9은 $\mathrm{LBPC}$ 와는 다르게 탄소함량이 약간 낮아지고, 산소와 칼륨, 구리, 아연 등이 검출되었는데, 이는 $\mathrm{KOH}$ 활성화 처리 과정에서 칼륨과 산소 및 시약 내 불순물 등이 LBPC에 일부 도핑된 것으로 판단된다.

탄소 소재를 화학적·물리적으로 활성화하면 소재 내에 미세.중기공이 형성되어 소재의 비표면적이 증가하게 된다. 이렇게 생성된 미세중기공은 이온 흡착 사이트를 제공하여 전해질의 이온수송능력을 증가시킨다(Xia et al., 2008; Jiang et al., 2020). $\mathrm{KOH}$ 활성화 처리 온도에 따른 비표면적 변화를 BET 분석을 통해 Table 3 에 정리하였다. LBPC의 비표면적은 $12.8 \mathrm{~m}^{2} / \mathrm{g}$ 으로 
낮은 값을 보였으며 KA-LBPC-6, KA-LBPC-7, KA-LBPC-8의 비표면적은 각각 1017.9, 2480.1, $1192.2 \mathrm{~m}^{2} / \mathrm{g}$ 으로 KOH 활성화 처리가 LBPC의 비표면적을 대폭 증가시켰다는 것을 확인할 수 있었다. 활성화 온도가 $700^{\circ} \mathrm{C}$ 였을 때 비표면적이 최대였고, 이보다 높은 온도일 때는 비표면적이 감소하는 것으로 나타났다. 이는 $700^{\circ} \mathrm{C}$ 까지는 미세기공과 중기공이 형성되면서 비표면적 이 증가하지만, $700^{\circ} \mathrm{C}$ 보다 높은 온도에서는 다공성 탄소 내 과활성화로 인해 기공 구조가 무너지면서 비표면적이 감소하는 것으로 판단된다(Kim and Hong, 1998; Rambabu et al., 2013). 다른 몇몇 연구사례에서 특정 온도 이상에서 탄소 소재의 활성화를 진행했을 때 비표면적이 감소한다고 보고된 바 있다(Kang et al., 2007; Jung et al., 2007; Lee et al., 2012).

LBPC와 KA-LBPC-6 9의 질소 흡탈착 등온선을 Fig. 5(a)에 나타내었다. KA-LBPC-6 9은 Brunauerm.Emmett-Teller가 분류한 type I의 형태를 나타내었다(Brunauer et al., 1938). 질소 흡탈착 등온선은 일정 온도에서 압력에 따른 시료의 질소 흡탈착 부피를 측정한 것으로 시료의 비표면적을 계산할 수 있다. LBPC의 흡착량은 극히 미미하였고, KA-LBPC-6과 KA-LBPC-8은 상대압력 $\left(\mathrm{P} / \mathrm{P}_{0}\right) \quad 0.1$ 까지 대부분이 흡착되었으며 0.1 이후로는 일정한 흡착량을 보였다. 이와는 좀 다르게 KA-LBPC-7과 KA-LBPC-9는 P/P $\mathrm{P}_{0}$ 0.7까지 흡착량이 증가하는 모습을 보였다. 이는 KA-LBPC-6, 8 그리고 KA-LBPC-7, 9가 비슷한 미세기공분율이기 때문으로 판단된다. 최종 흡착량은 KA-LBPC-7이 가장 높았으며, 그다음은 KA-LBPC-8, KA-LBPC-6, KA-LBPC-9의 순이었다. 이것은 비표면적의 결과와 같았다.

Fig. 5(b)는 LBPC와 KA-LBPC-6 9의 Barrett, Joyner, and Halenda (BJH) 그래프를 나타낸 것이다. 이 그래프에서는 $2 \mathrm{~nm}$ 이상의 크기를 가진 중기공분포를 알 수 있다. KA-LBPC-7에서 2 20 nm 범위에서 중기공이 가장 많이 성장한 것으로 나타났으 며, KA-LBPC-7를 제외한 다른 시료들은 중기공의 형성 정도가 미미하였다.

Fig. 5(c)는 LBPC와 KA-LBPC-6 9의 micropore (MP) 분포를 나타낸 것으로 직경에 따른 미세기공의 형성 정도를 확인할 수 있다. Fig. 5(c) 상에서 KA-LBPC-6, 8은 $0.9 \mathrm{~nm}$ 부근에서, KA-LBPC-7은 $1.2 \mathrm{~nm}$ 에서, KA-LBPC-9는 $1.6 \mathrm{~nm}$ 부근에서 각각 미세기공 크기 분포의 최대치를 보였다.

\section{3. 리그닌 기반 다공성 탄소의 전기화학적 특성}

KA-LBPC-6 9의 모든 주사 속도에서의 CV 곡선을 Fig. 6(a), 6(b), 6(c), 6(d)에 각각 나타내었다. KA-LBPC-6 9의 CV 곡선은 모두 기울어진 방추형 곡선 모양을 보였다. Fig. 6(e)는 스캔 속도 $200 \mathrm{mV} / \mathrm{s}$ 에서 KA-LBPC-6 9의 CV 곡선을 함께 나타낸 것이다. $x$ 축이 인가전압, $\mathrm{y}$ 축이 전류밀도인 $\mathrm{CV}$ 곡선의 면적은 단위면적당 전하량을 의미한다. Fig. 6(e)상에서 $\mathrm{CV}$ 곡선의 면적은 KA-LBPC-7이 가장 넓었으며, KA-LBPC-8, 9, 6의 순서대로 작아졌다. CV 곡선으로부터 계산한 비정전용량을 Fig. 6(f)에 나타내었다. 2-200 mV/s 주사 속도범위에서 KA-LBPC-6의 비정전용량은 $16.7,14.3,12.7,10.5,8.9,7.2,5.6$ $\mathrm{F} / \mathrm{g}$ 이었으며, KA-LBPC-7의 경우는 $151.3,121.9,95.6,65.6,48.7,35.4,24.6 \mathrm{~F} / \mathrm{g}$, KA-LBPC-8의 경우는 23.7, 22.2, 21.0, $18.9,16.8,14.0,10.3 \mathrm{~F} / \mathrm{g}, \mathrm{KA}-\mathrm{LBPC}-9$ 의 경우는 $25.3,23.0,21.2,18.2,15.3,11.7,8.0 \mathrm{~F} / \mathrm{g}$ 이었다. 활성화 과정에서 성장한 미세.중기공이 이온저장능력을 높여서 정전용량을 향상시키므로(Xia et al., 2008; Jiang et al., 2020), 비표면적이 증가함에 따라 비정전용량도 같이 증가할 것으로 예상했으나, 실제 결과에서는 비표면적이 $1200 \mathrm{~m}^{2} / \mathrm{g}$ 이하인 KA-LBPC-6, 8,9 간에는 비정전용량의 증가가 나타나지 않았다. 반면 비표면적이 $2480.1 \mathrm{~m} 2 / \mathrm{g}$ 으로 다른 KA-LBPC보다 두 배 이상 높았던 KA-LBPC-7 은 $2 \mathrm{mV} / \mathrm{s}$ 에서 비정전용량이 약 6 9배로 크게 증가했다. Fig. 7은 0.1 0.8 V의 전압범위에서 KA-LBPC-7의 충방전 테스트 결과를 나타낸 것이다. 충방전 곡선은 삼각형에 가까울수록 전기화학적 성능이 좋다고 할 수 있으며(Kim and Park, 2011; Hur et al., 2012), KA-LBPC-7의 경우는 비교적 삼각형에 가까운 곡선 모양을 나타내었다.

\section{4. 결론}

본 연구에서는 KL과 acrylonitrile을 그라프트 중합하여 얻은 리그닌-PAN 공중합체를 탄화하여 LBPC를 제조하였으며, 이를 $600 \sim 900^{\circ} \mathrm{C}$ 온도 범위에서 $\mathrm{KOH}$ 로 활성화하여 얻은 $\mathrm{KA}-\mathrm{LBPC}$ 의 물리적·전기화학적 특성을 알아보았다.

$\mathrm{KA}-\mathrm{LBPC}$ 를 SEM으로 관찰하였을 때는 $\mathrm{KOH}$ 활성화 처리에 의해 미세기공이 발달한 것을 시각적으로 확인할 수 있었다. $\mathrm{BET}$ 비표면적 분석 결과에서는 $\mathrm{KOH}$ 활성화 처리가 $\mathrm{LBPC}$ 의 비표면적을 대폭 증가시켰음을 알 수 있었다. 그중 $700^{\circ} \mathrm{C}$ 에서 $\mathrm{KOH}$ 활성화한 시료인 KA-LBPC-7이 비표면적 $2480.1 \mathrm{~m}^{2} / \mathrm{g}$, 미세기공부피 $0.64 \mathrm{~cm}^{3} / \mathrm{g}$, 중기공부피 $0.76 \mathrm{~cm}^{3} / \mathrm{g}$ 으로 비표면적 특성이 가장 우수하였음을 확인하였다. 또한 KA-LBPC-7의 비정전용량은 $151.3 \mathrm{~F} / \mathrm{g}(2 \mathrm{mV} / \mathrm{s})$ 으로 가장 우수하였다.

미세·중기공의 성장에 따른 비표면적의 증가가 이온저장능력을 높여 정전용량을 향상시킨다는 점에서 에너지 저장용 전극 소재로 이용하기 위한 리그닌-PAN 공중합체 기반 다공성 탄소의 활성화 처리 조건은 $\mathrm{KOH}$ 를 사용하여 $700^{\circ} \mathrm{C}$ 에서 1 시간 활성화 처리하는 것이 가장 적절한 것으로 나타났다. 